\title{
RESEARCH IN PUBLIC TORT LIABILITY
}

\author{
Patterson H. French*
}

The problem of government liability for torts has been attacked from many angles in statutes, judicial opinions, and the writings of researchers since Russell $v$. Men of Devon. ${ }^{1}$ To the practicing attorney the question is usually one of trying to make sense, from his client's point of view, out of a confusing mass of precedents about governmental and proprietary functions, legislative and ministerial acts, statutory relaxations of immunity and other legal snags and snarls. The judge has a similar problem, except that he does not have the advantage of knowing from the beginning the conclusion that he wants to reach. Writers of monographs and articles delve into the same material to point out the trends and theories in the constant conflict between public immunity and public responsibility.

In addition to the people who strive to obtain light and leading from the law books, there is another group of people who are closer to the firing line, but whose wisdom seldom gets into print. These are the law officers whose job it is to handle the claims that are made against a governmental unit. They range all the way from the part-time attorney for the small town to the scores of full-time lawyers who staff the legal department of a large unit of government.

In a way, the city attorney to whose desk comes a claim against his city is in the same position as the lawyer who represents the claimant. Both represent adversaries in a legal battle and the law theoretically provides a system by which the decision will go in favor of the combatant with the law on his side. The lawyer with a public body for his client can, with good logic, say that his job consists of using all legally proper means of preventing recovery by the claimant-initial rejection of every claim, the use of all legitimate methods of delay and obstruction, and a defense of the action to the bitter end. Relaxation of the rules of battle need to be made only where it would cost the city more to go on fighting than to compromise. Such an approach may save the city money, it neatly avoids puzzling questions of a sociological nature, and it follows the lines of thinking that government counsel, as well as lawyers in private practice, have absorbed from their legal education and their experience. Naturally, therefore, it tends to be a common method of procedure.

* B.A., 1928, Pomona College; LL.B., I93I, Harvard University, Ph.D., 1933, Columbia University. Member of the staff of the Office of Price Administration. Assistant Professor of Government, Yale University, 1937-1940; Assistant Secretary, Committee on Public Administration, Social Science Rescarch Council, r940-1942.

${ }_{2}$ T. R. 667 , roo Eng. Rep. 359 (1788). 
No matter how closely the adversary system is followed, the legal staffs of public bodies are in daily contact with an aspect of the problem that has received surprisingly little systematic study. The legal branch is almost necessarily the administrative center for the handling of tort claims against any governmental unit. Administrative problems begin with the difficulty of getting prompt and adequate notice of claims and continue through the investigation of claims, the determination of actual damage, and the organization of the legal staff for its many functions, to the final problem of making a virtually final decision on the case itself.

It is common for the legislative body to reserve to itself the final decision on the payment of claims except as these claims go to the courts. In practice, however, the burden of investigation and recommendation actually falls on the law officers. Whatever the legal theory may be, it is the legal staff in almost all of our governmental units that really decides what shall be done in a given case. The implication, that claimants must usually look to the law department for a decision as to their fate rather than to the legislative branch, the executive head, or even to the courts, is probably little realized.

As anyone who is connected with the process soon realizes, public tort business does not consist primarily of taking cases through the courts for judicial decisions on their merits. Instead, there is a sifting process by which many claims never become formal legal actions, few reach the courts, fewer still reach the point of judicial decision, and only a handful are concluded with executed judgments. In the five cities in which studies described below have been made under the auspices of the Committee on Public Administration of the Social Science Research Council, the work of the law department in disposing of cases before suit was a crucial point in a large majority of instances. When the law officers reject a claim or offer to settle at a greatly reduced figure, many parties have no practicable alternative. The delay, expense, and uncertainty of legal action, especially where the claimant and his attorney must compete against specialists in the handling of tort business, often seem to be insurmountable obstacles, particularly to claimants whose damages do not run into large figures.

The administrative problems of tort business grow, and to some extent change, as we deal with larger units of government. The law officer of a small town may not have to bother greatly about a formalized claim procedure, and his concern with techniques of investigation may be merely that of deciding how far he can look into the case himself. An office handling hundreds or thousands of claims a year must deal with the same problems in a more highly organized way, by developing claims forms, working out specialized machinery for the investigation of claims, and planning the flow of work so that the available staff will be used most effectively.

Somewhat surprisingly, there has been little study of the administrative problems of public tort liability. Perhaps the reason is that these problems seem to be day-today matters that each agency must solve for itself as it goes along. It is easy for a legally-trained staff to regard each claim as a separate case, to be handled as the 
circumstances seem to require, rather than as an integral part of a process that should be looked at as a whole. Perhaps, also, students with legal backgrounds are drawn toward research in more exclusively legal questions while students of public administration feel a natural hesitation about coping with problems in a technical field in which they are not specially trained.

Whatever the reason, the systematic information that would seem to be essential in improving the confused and unsatisfactory treatment of public tort liability has been almost entirely lacking. Almost nothing has been available, for instance, on the kinds of accidents that have led to claims, the kinds of injuries involved, the number of claims, or the amounts of damages that were asked. Without information of this kind, discussions of relaxing governmental immunity, revising the laws of notice, or increasing the deciding-power of law departments would seem to be discussions in a vacuum. As to administration itself, the five studies stimulated by the Committee on Public Administration and the parallel studies in Virginia brought to light many improvements in organization and methods that might be widely useful if more jurisdictions knew about them. It is even valuable to make law departments selfconscious about the apparent but unappreciated fact that they are, to all intents and purposes, quasi-judicial bodies in many cases where their seemingly informal opinions have the effect of final judgments.

The first large-scale attempt to meet this need for information has been undertaken over the last five years, and many of its results are reflected in the other articles in the present volume. The enterprise was confined to the administration of municipal tort liability, and detailed information is now available for five cities ranging in size from Chicago to Medford, Massachusetts. Comparable information is available for most of the cities in Virginia. This is only a first step, to point the way toward getting intimate and detailed pictures of other jurisdictions. The basic information is useful in itself, and it will have more than served its purpose if it leads to further research, serves as a guide to methods of procedure, and stimulates thought about the philosophy and public policy of our present system of tort liability.

The project evolved out of an interest in problems of public tort liability shared by two groups. The Committee on Public Administration of the Social Science Research Council has recognized throughout its existence the importance of research in administrative problems outside the strict sphere of government. The American Bar Association's Section on Municipal Law, through its Committee on Municipal Liability, has been turning its thought to the problems of public liability from many angles. These two groups, stimulated by Professor Edwin M. Borchard of the Yalc Law School and Professor Oliver P. Field of the University of Indiana among others, began in 1936 to consider methods of encouraging research on the subject.

A wealth of profitable experience in research technique resulted from the attempt to bring together two allied but distinct disciplines, to stimulate agencies to study themselves, and to carry on collaborative research in a field with no existing guideposts. The project stands as evidence that the gap can be bridged between the legal fraternity, which may tend to concentrate on the legal approach to individual cases 
rather than on general administrative analysis, and the public administration group, which approaches its problems with a limited technical knowledge of the legal practitioner's problems. The successful stimulation of studies in various parts of the country, with a small central staff and with no great expenditure of funds, demonstrated again, as the city manager studies of the Committee on Public Administration had demonstrated earlier, that collaborative research is feasible and fruitful.

Several points became clear early in the planning of the research program. A number of localities should be studied, both to observe similarities that might lead to general conclusions and to observe the effects of local variations arising from different legal provisions, special local conditions, particular administrative techniques, and differences in the size of the governmental units. Since most of the facts to be studied were in the files of the law departments, it was necessary to obtain the cooperation of city attorneys in opening their records for study. (An incidental result was that the cities chosen for investigation would be those in which the law department was already sensitive to the need for good administration. This "loading" was avoided, to a considerable extent, in George A. Warp's Virginia studies, where an attempt was made to cover the entire state.) If an active member of the city's own legal staff could be induced to take part in the study, the possibility of getting full information and accurate analyses would be greatly increased.

The lack of past studies raised at once the question of outlining the field so that possible collaborators could be shown the kind of work that the project involved and so that the final results would have collective meaning. One method that might have been effective would have been to call together a group of specialists for a conference to set forth the kind of information that was needed. Although this technique had been employed very effectively by the Committee on Public Administration in other instances, it seemed better in this case to explore the field directly and to discover possibilities and obstacles through a sample study in a particular locality. One reason for the decision was the novelty of the field; any conference would have been handicapped by the almost complete lack of people who could report on their experiences with research of this kind.

The first study-one that served both in its content and in its method of attack as a model for later studies-was undertaken in Los Angeles. It was conducted by Leon T. David, Assistant City Attorney in charge of the Tort Claims Division there. Mr. David had been chairman of the Attorneys' Section of the California League of Municipalities and was on the faculty of the University of Southern California Law School. As the author of several definitive publications on the law of municipal tort liability, he combined an objective point of view with active experience in administering a large office dealing directly with the problems about which he was to write. Mr. David enlisted as a collaborator John F. Feldmeier of the California Bar, who undertook to examine the records of nearly 1,500 tort claims against the city.

Very early in the Los Angeles study the general outlines of the subject were drawn in a set of questions developed by Charles S. Ascher of the Committee on Public Administration and Mr. David, with advice and suggestions from a number 
of others. These questions served the useful purpose of pointing out systematically, for the first time, the elements in need of attention. The legal background was covered, to set the stage for further research: the extent of existing tort liability, notice to the city, the filing of the claim, the pleading of liability, the place where a claim must be presented, and the personal liability of public officers. Another large field was opened up with a series of questions about the claims themselves: kinds of injuries involved, causes of the injuries, number of claims filed, amounts of damages involved, age and sex of claimants, and the method of final disposition of the claims. Questions were directed at the administrative process within the law department: the steps in handling claims, division of work within the legal staff, methods of investigation, and the process of decision or recommendation within the law department. The outline served as a guide, not only for the Los Angeles studies, but also for the later ones and for any independent research that might develop on the subject.

The Los Angeles study was begun in 1938 and was published by the Committee on Public Administration in r939. It reported on 1,458 claims filed between January I, x935, and June 30, 1938. The text, which followed the general outline of the pilot questions, was supplemented by twenty-seven tables of statistical material and an appendix that reproduced the forms used by the city for the various steps in the claims process. The pilot questions, which were followed generally in the textual presentation, were reproduced for the use of later workers.

The stimulation of collaborative studies was undertaken by the staff of the Committee on Public Administration with the help of Professor Borchard's committee of the American Bar Association, the American Municipal Association, and the Institute of Municipal Law Officers, and other interested groups. There was, naturally, interest in the idea in a number of places where plans could not be brought to final fruition because of the lack of personnel, incompleteness of the records, or other factors. Some of the cities in which interest was expressed were Cincinnati, San Francisco, Oakland, Denver, New Haven, and Buffalo. Studies were finally undertaken in Chicago, Boston, Austin, Washington, D. C., and Medford, Massachusetts. A study of North Carolina cities undertaken by Robert S. Rankin of Duke University was not carried to completion along the line of the others because there were so many cities in which records were woefully incomplete. At the same time the Bureau of Public Administration of the University of Virginia undertook a study of Virginia cities under George A. Warp.

The projects were undertaken in each case with the approval and the cooperation of the head of the city's legal staff, a necessary element if records and personnel were to be used effectively. Much credit must be given to the city attorneys who recognized the importance of the work, especially when there are still many localities in which administrators of legal departments find it hard to think administratively. The research was undertaken in Chicago by Paul A. H. Shults, Assistant Corporation Counsel in charge of tort litigation, with the assistance of Thelma Brook Simon of the University of Chicago Law School and the Illinois bar. The study of Medford. 
Massachusetts, was made by Mark E. Gallagher, Jr., City Solicitor. The Boston report was prepared by Edgar Fuller of the Harvard University faculty, who had written previously on the tort liability of school districts. Austin was studied by Gus Levy, first of the Bureau of Municipal Research of the University of Texas and later Personnel Director for the City of Austin. The report on Washington was undertaken by Robert Ferguson of the George Washington University Law School, under the direction of Professor John A. McIntire.

All of these studies have been completed and are now available, with the exception of Washington, D. C. They cover, along the lines of the pilot questions and the Los Angeles report, the legal and administrative problems of their cities through an analysis of claims filed for periods ranging from I933 to I939 in Austin to I937 to I939 in Chicago. Edgar Fuller's study was published in June, I94I, by the Bureau for Research in Municipal Government of the Harvard Graduate School of Public Administration under the title, "Tort Liability of Municipalities in Massachusetts." An article using much of the same material was published by Edgar Fuller and A. James Casner in the Harvard Law Review for January, I94I, entitled "Municipal Tort Liability in Operation." An article by Paul A. H. Shults is to appear in the John Marshall Law Quarterly. George A. Warp's study, "Municipal Tort Liability in Virginia" was published by the Bureau of Public Administration of the University of Virginia in I94I. A summary and consensus by the present author, based on all of this material, has been prepared by the Committee on Public Administration for limited release. Other articles ${ }^{2}$ in this symposium have made use of the material.

A final step in the research program contributed greatly to clarifying ideas and outlining possible next steps. This was a two-day conference, arranged by the Committee on Public Administration in September, I94I, at which all of the material was discussed by fourteen people, including the authors, the Committee's staff, and others. Much of the discussion turned on the relation of the newly gathered material to statutory changes affecting governmental immunity, notice, and the settlement of claims. It seems safe to say that the conference progressed with an effectiveness that would have been impossible if a body of useful material had not been available for its use.

The studies offer a body of fresh, first-hand facts and analyses not previously in existence. The process of planning, stimulating, and supervising the studies brought to light a number of points that may not be readily evident in the reports and yet may be important to record for the benefit of other workers on the subject. The general method of procedure has already been described; some of its by-products and implications can be mentioned.

One of the most noticeable points that the enterprise brought out was the lack of effective record-keeping, even in many cities that seemed to be well administered in other ways. Robert S. Rankin's study in North Carolina was prevented from proceeding along the course first planned and George A. Warp's work in Virginia was greatly complicated by the incompleteness of records covering cases settled without

'David, Public Tort Liability Administration: Basic Conflicts and Problems, infra p. 335; David and French, Public Tort Liability Administration: Organizations, Methods, and Expense, infra. 
trial, amounts paid, the nature of injuries, and other seemingly fundamental data. Even the cities in which studies were completed, where records were in a relatively advanced state, did not supply more than the raw data with which to work. City attorneys and their staffs have paid attention only in a few places to the need for having records in such form that they can be viewed with an eye to improvements in methods, changes in statutes, and modifications of general attitudes.

The very specific material on claims and their disposition in the Committee's studies contributes to the solution of a number of problems. We are beginning to know, for instance, what activities of government are likely to result in claims. We have detailed tables on the kinds of injuries for which claims are made. We know the kinds, amounts, and frequency of claims in cities of various size, and we can draw some conclusions as to the importance of such special factors as ice and snow or the condition of repair in public buildings. We also know where the gaps in our information lie. We do not yet have information about the kinds of injuries that never lead to claims, either because the city is protected by its governmental immunity or because the injured parties do not consider the process of making a claim to be worth their while. We do not yet have statistics to show the individual hardships imposed by the various injuries; the formal ad damnum gives little information about the real loss and less about the actual burden. Information of this kind requires extensive field work, but the results would cast light where there is now almost complete darkness.

The picture of tort business as an administrative as well as a legal activity is documented by the studies in a number of ways. The organization of a law department for a large volume of work is set forth in the Chicago and Los Angeles studies. Comparisons can be made of experience in various cities on particular problems, such as the use of official claims forms and variations in the length of time for filing notice of a claim. The studies show the usefulness of some medium for the exchange of information about methods of handling tort business. Boston and Chicago, for instance, belong to accident-reporting services that are operated privately for the benefit of insurance companies, transit companies, and other agencies that are subjected to frequent claims. Chicago's method of coordination between the Law Department and the Police Department in the reporting and photographing of accidents might be studied by cities that face a similar problem. Los Angeles has used aerial photography to advantage in the case of floods. Austin can contribute evidence about the effect of liberally interpreting the time limit on the filing of claims. It is easy to dismiss the experience on these points as matters of common knowledge or problems that each city must work out for itself. When we consider, on the other hand, the thousands of jurisdictions that face the same problem and the few jurisdictions that can claim to have reached a state of perfection, the opportunities for an exchange of information appear almost endless.

The studies give the basis for some careful thought about the process of decision as it takes place, largely unconsciously, in the law department. The point becomes very real when figures are produced to show, for instance, that only about two per 
cent of the claims that are filed in Los Angeles go through the whole process from filing to judicial decision. Stripped of its case-to-case immediacy, the process becomes virtually a quasi-judicial one of weighing the merits of each claim and rendering a judgment which the claimant is not likely, because of the expense, delay, and complexity of the legal process, to dispute. The claimant cannot formally demand notice, hearing, and the other accoutrements of a quasi-judicial action because if his claim is rejected by the law department he can always take it to the courts for a trial de novo. In practice, however, the law department needs to recognize its responsibility of providing a method of uniform, objective decision to protect the claimant who views that department as his tribunal of last resort. Chicago's experience with its Settlement Committee, New York's method of leaving the decision to the Comptroller, and other methods need further study.

No matter how closely the adversary system is followed in the handling of public tort claims, the conflict between governmental immunity and public responsibility intrudes itself for consideration. The studies received their initial stimulus from groups that were interested in revising and clarifying the law of governmental liability for torts. The factual material that is now available may be useful in the future consideration of questions of the extension of liability, state cooperation with localities, and generally improved statutory treatment of the problem.

It is clear that the problem is much more than the disposal of individual cases, one after another. The work of any unit of government in defending itself against tort claims has its origin in tens or hundreds or thousands of individual accidents involving citizens or their property. Some of these incidents can be expected as almost inevitable parts of doing governmental business. Others may arise unexpectedly from an unbelievable variety of causes. The damage will be small in most cases, but a government never knows when a sudden mischance will bring in claims for staggering amounts. There will be some cases where the injury will create crucial economic problems for individuals or their families, and there will be other cases where troublesome people will make the most of the nuisance value of flimsy claims. Law departments may not find it possible to approach individual cases on the basis of such broad considerations, but any general analysis either of law or of practice must start from some such general point of view.

The principal contribution thus far is perhaps not the providing of concrete information, important as that has been. It may be more important to show that the thought and research methods of law and public administration can be merged along a line that is now beginning to be marked out. The war may create new problems of public tort liability, with blackouts, possible bombings, and new public activities that will result in new kinds of claims. The pressure of war activity may divert attention that would otherwise have been given to the tort field. The postwar period will undoubtedly bring up again the question of extending liability and of having the states play a larger part in equalizing risks, especially among the larger cities. The present work is only the beginning, but it may mark the way for much progress in later years. 